\title{
Sun leaves up-regulate the photorespiratory pathway to maintain a high rate of $\mathrm{CO}_{2}$ assimilation in tobacco
}

\section{Wei Huang*, Shi-Bao Zhang and Hong Hu}

Key Laboratory of Economic Plants and Biotechnology, Kunming Institute of Botany, Chinese Academy of Sciences, Kunming, China

\section{Edited by:}

Richard Sayre, New Mexico

Consortium at Los Alamos National

Labs, USA

\section{Reviewed by:}

Uener Kolukisaoglu, University of

Tuebingen, Germany

Nabil I. Elsheery, Tanta University,

Egypt

\section{*Correspondence:}

Wei Huang, Key Laboratory of Economic Plants and Biotechnology, Kunming Institute of Botany, Chinese Academy of Sciences, 132 Lanhei Road, Kunming, Yunnan 650201, China

e-mail: huangwei@mail.kib.ac.cn
The greater rate of $\mathrm{CO}_{2}$ assimilation $\left(A_{n}\right)$ in sun-grown tobacco leaves leads to lower intercellular and chloroplast $\mathrm{CO}_{2}$ concentrations and, thus, a higher rate of oxygenation of ribulose-1,5-bisphosphate (RuBP) than in shade-grown leaves. Impairment of the photorespiratory pathway suppresses photosynthetic $\mathrm{CO}_{2}$ assimilation. Here, we hypothesized that sun leaves can up-regulate photorespiratory pathway to enhance the $A_{n}$ in tobacco. To test this hypothesis, we examined the responses of photosynthetic electron flow $\left(J_{T}\right)$ and $\mathrm{CO}_{2}$ assimilation to incident light intensity and intercellular $\mathrm{CO}_{2}$ concentration $\left(C_{\mathrm{i}}\right)$ in leaves of ' $k 326$ ' tobacco plants grown at $95 \%$ sunlight (sun plants) or $28 \%$ sunlight (shade plants). The sun leaves had higher photosynthetic capacity and electron flow devoted to RuBP carboxylation $\left(J_{C}\right)$ than the shade leaves. When exposed to high light, the higher Rubisco (ribulose-1,5-bisphosphate carboxylase/oxygenase) content and lower $C_{\mathrm{i}}$ in the sun leaves led to greater electron flow devoted to RuBP oxygenation $\left(J_{O}\right)$. The $J_{O} / J_{C}$ ratio was significantly higher in the sun leaves than in the shade leaves under strong illumination. As estimated from $\mathrm{CO}_{2}$-response curves, the maximum $J_{\mathrm{O}}$ was linearly correlated with the estimated Rubisco content. Based on light-response curves, the light-saturated $J_{O}$ was linearly correlated with light-saturated $J_{T}$ and light-saturated photosynthesis. These findings indicate that enhancement of the photorespiratory pathway is an important strategy by which sun plants maintain a high $A_{n}$.

Keywords: $\mathrm{CO}_{2}$ assimilation, light acclimation, photorespiratory pathway, RuBP carboxylation, RuBP regeneration

\section{INTRODUCTION}

In natural habitats, plants are subject to temporal and spatial variations in light intensity. Many species modulate the biochemical composition and morphology of leaves or whole plants to acclimate to their light environments (Terashima and Hikosaka, 1995; Niinemets et al., 1998; Terashima etal., 2005; Yamori etal., 2010a). In general, the leaves of plants grown under high light (sun leaves) have higher levels of cytochrome $f$ (Cyt f), ATP synthase, Rubisco, and other Calvin Cycle enzymes (Evans, 1987; Terashima and Evans, 1988; Hikosaka, 1996; Hikosaka and Terashima, 1996; Yamori et al., 2010a). Those leaves that acclimate to more intense light usually have higher capacities for electron transport and $\mathrm{CO}_{2}$ assimilation (Yamori etal., 2010a). Timm etal. (2012) have reported that over-expression of the H-protein of glycine decarboxylase (a key enzyme in the photorespiratory pathway) leads to considerably increased net photosynthesis in Arabidopsis thaliana, suggesting that enhancement of photorespiratory pathway potentially improves the $A_{\mathrm{n}}$. However, the relationship between photorespiration and photosynthesis in plants acclimated to high light is unclear.

\footnotetext{
Abbreviations: $A_{\mathrm{n}}$, rate of $\mathrm{CO}_{2}$ assimilation; $C_{\mathrm{a}}$, atmospheric $\mathrm{CO}_{2}$ concentration $C_{\mathrm{i}}$, intercellular $\mathrm{CO}_{2}$ concentration; $g_{\mathrm{s}}$, stomatal conductance; $J_{\mathrm{C}}$, electron flow devoted to carboxylation of RuBP; $J_{\max }$, maximum rate of RuBP regeneration; $J_{\mathrm{O}}$, electron flow devoted to oxygenation of RuBP; $J_{\mathrm{T}}$, photosynthetic electron flow; Rubisco, ribulose-1,5-bisphosphate carboxylase/oxygenase; RuBP, ribulose1,5-bisphosphate; $V_{\mathrm{cmax}}$, maximum rate of RuBP carboxylation.
}

In some species, the greater $A_{\mathrm{n}}$ by plants grown under and adapted to high light means that they have lower intercellular and chloroplast $\mathrm{CO}_{2}$ concentrations than those acclimated to low light (Hanba et al., 2002; Oguchi et al., 2005; Yamori et al., 2010a). When the chloroplast $\mathrm{CO}_{2}$ concentration is low, the specificity of Rubisco to $\mathrm{O}_{2}$ increases and then induces a rise in the rate of oxygenation of RuBP. Under such conditions, the higher Rubisco content in sun leaves accelerates the rate of RuBP oxygenation. During RuBP oxygenation, one molecule of glycolate-2-phosphate and one of glycerate-3-phosphate are formed (Ogren, 1984). Glycolate-2phosphate cannot be used by plants for biosynthetic reactions and is a potential inhibitor of chloroplast functioning (Anderson, 1971). Therefore, it must be converted into glycerate-3-phosphate through the photorespiratory pathway (Leegood et al., 1995). To avoid this side effect of glycolate-2-phosphate, it is speculated that the capacity of photorespiratory pathway is greater in sun leaves than in shade leaves. Results from previous studies have shown that the effect of the light environment on the capacity of that pathway is controversial. For example, growth irradiance can influence photorespiration in leaves from Arisaema heterophyllum and Swietenia, but not from Dipteryx (Muraoka et al., 2000; Marenco et al., 2001).

According to the $\mathrm{C}_{3}$ photosynthesis model, the $A_{\mathrm{n}}$ is limited by both RuBP carboxylation and RuBP regeneration (Farquhar et al., 1980). In both sun and shade leaves of tobacco plants grown with high nitrogen supply, the $A_{\mathrm{n}}$ at $C_{\mathrm{a}}$ and high light tends to be limited by RuBP regeneration (Yamori et al., 2010a). Because 
the Calvin Cycle intermediate glycerate-3-phosphate is critical for RuBP regeneration, impairment of the recycling of glycolate-2phosphate into glycerate-3-phosphate depletes RuBP regeneration and, ultimately, depresses the $A_{\mathrm{n}}$ (Somerville and Ogren, 1980, 1981, 1983; Takahashi et al., 2007). Therefore, we hypothesize that up-regulation of the photorespiratory pathway may be an important strategy by which plants grown under high light can accelerate RuBP regeneration and subsequently maintains the high rate of photosynthesis.

The aim of this study was to investigate further the role of the photorespiratory pathway in photosynthesis. Plants of Nicotiana tabacum were grown at $24 / 18^{\circ} \mathrm{C}$ (day/night) under either 95 or $28 \%$ sunlight. The $A_{\mathrm{n}}$ and $J_{\mathrm{T}}$ to incident light intensity were evaluated at $24^{\circ} \mathrm{C}$ and a $\mathrm{CO}_{2}$ concentration of $400 \mu \mathrm{mol} \mathrm{mol}^{-1}$. Those same parameters were also examined in response to incident $\mathrm{CO}_{2}$ concentration when plants were exposed to $24^{\circ} \mathrm{C}$ and $1200 \mu \mathrm{mol}$ photons $\mathrm{m}^{-2} \mathrm{~s}^{-1}$. Our results indicated that sun leaves indeed up-regulate the photorespiratory pathway to maintain a high photosynthesis rate.

\section{MATERIALS AND METHODS PLANT MATERIALS AND GROWTH CONDITIONS}

Seedlings of the ' $k 326$ ' cultivar of tobacco (Nicotiana tabacum) were cultivated in plastic pots, and then transferred to a phytotron at Kunming Institute of Botany, Yunnan, China (elevation 1900 $\left.\mathrm{m}, 102^{\circ} 41^{\prime} \mathrm{E}, 25^{\circ} 01^{\prime} \mathrm{N}\right)$. Conditions included day/night temperatures of $24^{\circ} \mathrm{C} / 18^{\circ} \mathrm{C}, 60 \%$ relative air humidity, and a constant $C_{\mathrm{a}}$ of $400 \mu \mathrm{mol} \mathrm{mol}{ }^{-1}$. Sunlight was used as the source of illumination in the phytotron. Sun plants received approximately 95\% of full sunlight (maximum intensity at noon $\approx 1990 \mu \mathrm{mol}$ photons $\mathrm{m}^{-2} \mathrm{~s}^{-1}$ ). To establish shade conditions, we added a layer of netting over other plants to reduce photosynthetic active radiance to approximately $28 \%$ of full sunlight (maximum intensity $\approx 580 \mu \mathrm{mol}$ photons $\mathrm{m}^{-2} \mathrm{~s}^{-1}$ ). During the experimental period (24 October to 24 December 2013), none of the plants experienced any water or nutrient stresses. After 50 days, the mature leaves that had been produced since transplanting were chosen for photosynthetic measurements.

\section{CHLOROPHYLL FLUORESCENCE AND GAS EXCHANGE MEASUREMENTS}

An open gas exchange system incorporating infrared $\mathrm{CO}_{2}$ and water vapor analyzers (Li-6400XT; Li-Cor Inc., Lincoln, NE, USA) was used to determine the $A_{\mathrm{n}}$ in the phytotron. During the measurement period, the relative air humidity was $60 \%$ and the air temperature was $24^{\circ} \mathrm{C}$. To generate a light response curve, the leaves of both sun and shade plants were exposed to high light (i.e., $1200 \mu \mathrm{mol}$ photons $\mathrm{m}^{-2} \mathrm{~s}^{-1}$ ) for $20 \mathrm{~min}$ to obtain a steady state. Afterward, photosynthetic parameters were evaluated every $2 \mathrm{~min}$ at a controlled $C_{\mathrm{a}}$ of $400 \mu \mathrm{mol} \mathrm{mol}{ }^{-1}$ and photosynthetic photon flux densities(PPFDs) of 2000, 1600, 1200, 800, 500, 300, 200, 100, 50,20 , or $0 \mu \mathrm{mol}$ photons $\mathrm{m}^{-2} \mathrm{~s}^{-1}$. The $\mathrm{CO}_{2}$ assimilation rate versus $C_{\mathrm{i}}$ was measured (von Caemmerer and Farquhar, 1981) at $1200 \mu \mathrm{mol}$ photons $\mathrm{m}^{-2} \mathrm{~s}^{-1}$. For each $A / C_{\mathrm{i}}$ curve, photosynthetic rate reached a steady state at $400 \mu \mathrm{mol} \mathrm{mol}^{-1}$, subsequently decreased to a lower limit of $50 \mu \mathrm{mol} \mathrm{mol}^{-1}$ and then increased stepwise to an upper limit of $2000 \mu \mathrm{mol} \mathrm{mol}^{-1}$. Each stepwise measurement was completed within 2-3 min. Using those $A / C_{\mathrm{i}}$ curves, we calculated the maximum rates of RuBP regeneration $\left(J_{\max }\right)$ and RuBP carboxylation $\left(V_{\mathrm{cmax}}\right)$ according to the method of Long and Bernacchi (2003). The leaf Rubisco content was estimated according to the empirical equation of Yamori et al. (2010a) as $y=35.3 x+6.6$, where $y$ is $V_{\mathrm{cmax}}\left(\mu \mathrm{mol} \mathrm{CO} \mathrm{m}^{-2} \mathrm{~s}^{-1}\right)$ and $x$ is Rubisco content $\left(\mu \mathrm{mol} \mathrm{m}{ }^{-2}\right)$.

Chlorophyll fluorescence was measured simultaneously with gas exchange measurements using a fluorometer chamber (640040; Li-Cor Inc.). The fluorescence parameters $F_{\mathrm{s}}$ and $F_{m}{ }^{\prime}$ were determined as previously described (Baker and Rosenqvist, 2004), with $F_{\mathrm{S}}$ representing the steady fluorescence and $F_{m}{ }^{\prime}$ the maximum fluorescence after light-adaptation. The effective quantum yield of PSII was calculated as $\Phi_{\text {PSII }}=\left(F_{m}{ }^{\prime}-F_{\mathrm{s}}\right) / F_{m}{ }^{\prime}$ (Genty et al., 1989).

\section{ESTIMATING THE RATE OF PHOTOSYNTHETIC ELECTRON FLOW}

The total $J_{\mathrm{T}}$ through PSII $\left(J_{\mathrm{T}}\right)$ was calculated as $J_{\mathrm{T}}=\Phi_{\text {PSII }} \times$ PPFD $\times 0.85 \times 0.5$ (Krall and Edwards, 1992). Because leaf absorbance $\left(L_{a b s}\right)$ in tobacco differs little between sun and shade leaves (Miyake et al., 2005), we assumed here that $L_{a b s}$ was 0.85 in both types. The constant of 0.5 was used based on the assumption of an equal distribution of photons between photosystems I and II (Miyake et al., 2005). The light saturation point (LSP) is the PPFD that causes $95 \%$ of the maximum $A_{n}$ while the light compensation point (LCP) is the PPFD under which the net photosynthetic rate is 0 . If $\mathrm{CO}_{2}$ assimilation is limited in the leaves, the water-water cycle cannot eliminate excess excitation energy by acting as a major alternative electron sink (Driever and Baker, 2011). Therefore, we allocated the electron flow through PSII to RuBP carboxylation $\left(J_{\mathrm{C}}\right)$ and oxygenation $\left(J_{\mathrm{O}}\right)$. These were estimated according to the method of Valentini et al. (1995):

$$
\begin{gathered}
J_{\mathrm{O}}=2 / 3 \times\left(J_{\mathrm{T}}-4 \times\left(A_{\mathrm{n}}+R_{\mathrm{d}}\right)\right) \\
J_{\mathrm{C}}=1 / 3 \times\left(J_{\mathrm{T}}+8 \times\left(A_{\mathrm{n}}+R_{\mathrm{d}}\right)\right)
\end{gathered}
$$

where $A_{\mathrm{n}}$ is $\mathrm{CO}_{2}$ assimilation and $R_{\mathrm{d}}$ represents the rate of mitochondrial respiration. We estimated $R_{\mathrm{d}}$ from the linear region of the light response curve between PPFDs of 20 and $100 \mu \mathrm{mol}$ photons $\mathrm{m}^{-2} \mathrm{~s}^{-1}$ (Zhang et al., 2009, 2013).

\section{STATISTICAL ANALYSIS}

The results were displayed as mean values of four independent measurements. Data were subjected to independent $t$-test using the SPSS 16.0 for windows (SPSS Inc., Chicago, IL, USA). A level of $P<0.05$ was used to determine whether differences were significant between sun and shade leaves.

\section{RESULTS}

Compared with the shade plants, the sun plants had significantly higher values for LSP, LCP, apparent quantum efficiency, and saturating photosynthetic rate (Table 1) as well as relatively higher $g_{\mathrm{s}}$ than the shade leaves (Figure 1A). When exposed to light intensities above $300 \mu \mathrm{mol}$ photons $\mathrm{m}^{-2} \mathrm{~s}^{-1}$, values for $C_{\mathrm{i}}$ were significantly lower in sun leaves $(P<0.0001$; Figure 1B). At 1200 $\mu \mathrm{mol}$ photons $\mathrm{m}^{-2} \mathrm{~s}^{-1}$, the $C_{\mathrm{i}}$ was 193 and $261 \mu \mathrm{mol} \mathrm{mol} \mathrm{m}^{-1}$ in the sun and shade leaves, respectively. When light intensities 
Table 1 | Parameters describing photosynthetic $\mathrm{CO}_{2}$ assimilation.

\begin{tabular}{lccl}
\hline & Sun leaves & Shade leaves & Significance \\
\hline $\begin{array}{l}\mathrm{LSP}(\mu \mathrm{mol} \text { photons } \\
\left.\mathrm{m}^{-2} \mathrm{~s}^{-1}\right)\end{array}$ & $1164 \pm 48.9$ & $797 \pm 18.5$ & 0.0004 \\
$\mathrm{LCP}(\mu \mathrm{mol}$ photons & $32 \pm 2.8$ & $20 \pm 3.6$ & 0.04 \\
$\left.\mathrm{~m}^{-2} \mathrm{~s}^{-1}\right)$ & $0.0685 \pm 0.003$ & $0.046 \pm 0.003$ & 0.0001 \\
$\begin{array}{l}\text { Apparent quantum } \\
\text { efficiency }\end{array}$ & $23.8 \pm 0.5$ & $13.6 \pm 0.8$ & 0.0001 \\
$\begin{array}{l}\text { Saturating } \\
\text { photosynthetic rate } \\
\left(\mu \mathrm{mol} \mathrm{CO}_{2} \mathrm{~m}^{-2} \mathrm{~s}^{-1}\right)\end{array}$ & & & \\
\hline
\end{tabular}

The light saturation point (LSP) is the PPFD at which the $A_{n}$ is $95 \%$ of the maximum, and the light compensation point (LCP) is the PPFD under which the net photosynthetic rate is 0 . Data are mean values $\pm S D(n=4)$. Significant differences between sun and shade leaves were examined by independent $t$-tests $(P<0.05)$.

were above $200 \mu \mathrm{mol}$ photons $\mathrm{m}^{-2} \mathrm{~s}^{-1}$, the sun leaves showed a higher $A_{\mathrm{n}}(P<0.0001$; Figure 1C). Under strong illumination, i.e., $2000 \mu \mathrm{mol}$ photons $\mathrm{m}^{-2} \mathrm{~s}^{-1}$, photosynthetic rate was 21.8 and $13.1 \mu \mathrm{mol} \mathrm{CO} \mathrm{m}^{-2} \mathrm{~s}^{-1}$ in sun and shade leaves, respectively. These results indicated that the sun leaves generally had greater photosynthetic capacity, which led to their lower $C_{\mathrm{i}}$ values.

The $J_{\mathrm{T}}$ through PSII was significantly higher in the sun leaves when light intensities were above $200 \mu \mathrm{mol}$ photons $\mathrm{m}^{-2} \mathrm{~s}^{-1}$ $\left(P<0.0001\right.$; Figure 2A). Maximum values for $J_{\mathrm{T}}$ were 217 and $95 \mu \mathrm{mol}$ electrons $\mathrm{m}^{-2} \mathrm{~s}^{-1}$ in sun and the shade leaves, respectively. Similarly, significantly more electron flow was devoted to RuBP carboxylation and oxygenation in the sun leaves, with maximum values of 135 and $69 \mu \mathrm{mol}$ electrons $\mathrm{m}^{-2} \mathrm{~s}^{-1}$ for $J_{\mathrm{C}}(P<0.0001$; Figure 2B $)$, and 82 and $26 \mu \mathrm{mol}$ electrons $\mathrm{m}^{-2} \mathrm{~s}^{-1}$ for $J_{\mathrm{O}}(P<0.0001$; Figure $2 \mathrm{C})$ in sun and shade leaves, respectively. We found it interesting that, at light intensities above $800 \mu \mathrm{mol}$ photons $\mathrm{m}^{-2} \mathrm{~s}^{-1}$, the sun leaves had significantly higher $J_{\mathrm{O}} / J_{\mathrm{C}}$ ratios than did the shade leaves $(P<0.0001$; Figure $2 \mathrm{D})$; maximum ratios were 0.6 (sun) and 0.4 (shade). These results demonstrated that capacity by the photorespiratory pathway was enhanced in the sun leaves.

The $A / C_{\mathrm{i}}$ curves indicated that sun leaves had higher rates of $\mathrm{CO}_{2}$ assimilation when $C_{\mathrm{i}}$ was higher than $90 \mu \mathrm{mol} \mathrm{mol}{ }^{-1}$ (Figure 3). The maximum photosynthetic rates in sun and shade leaves were 51.3 and $25.1 \mu \mathrm{mol} \mathrm{CO}_{2} \mathrm{~m}^{-2} \mathrm{~s}^{-1}$, respectively (Figure 3). Values for $J_{\mathrm{T}}$ and $J_{\mathrm{C}}$ were largely higher in the sun leaves under any $\mathrm{CO}_{2}$ concentration (Figures $4 \mathrm{~A}, \mathrm{~B}$ ), and they rose rapidly in parallel with $C_{\mathrm{i}}$ when it was below $300 \mu \mathrm{mol} \mathrm{mol}^{-1}$ (Figures 4A,B). When $C_{\mathrm{i}}$ was higher than $400 \mu \mathrm{mol} \mathrm{mol}^{-1}, J_{\mathrm{T}}$ was hardly increased in either type of leaf while $J_{C}$ increased only slightly. As $C_{\mathrm{i}}$ rose, $J_{\mathrm{O}}$ gradually declined in both sun and shade leaves. However, $J_{\mathrm{O}}$ values were always higher in the sun leaves, especially when the $\mathrm{CO}_{2}$ concentration was low. For example, at a $C_{\mathrm{i}}$ of $55 \mu \mathrm{mol} \mathrm{mol}{ }^{-1}, J_{\mathrm{O}}$ was 80 and $31 \mu \mathrm{mol}$ electrons $\mathrm{m}^{-2} \mathrm{~s}^{-1}$ in sun and shade leaves, respectively (Figure 4C). At low $C_{i}$, the affinity of Rubisco to $\mathrm{O}_{2}$ was markedly increased, and operation of the photorespiratory pathway consumed most
A

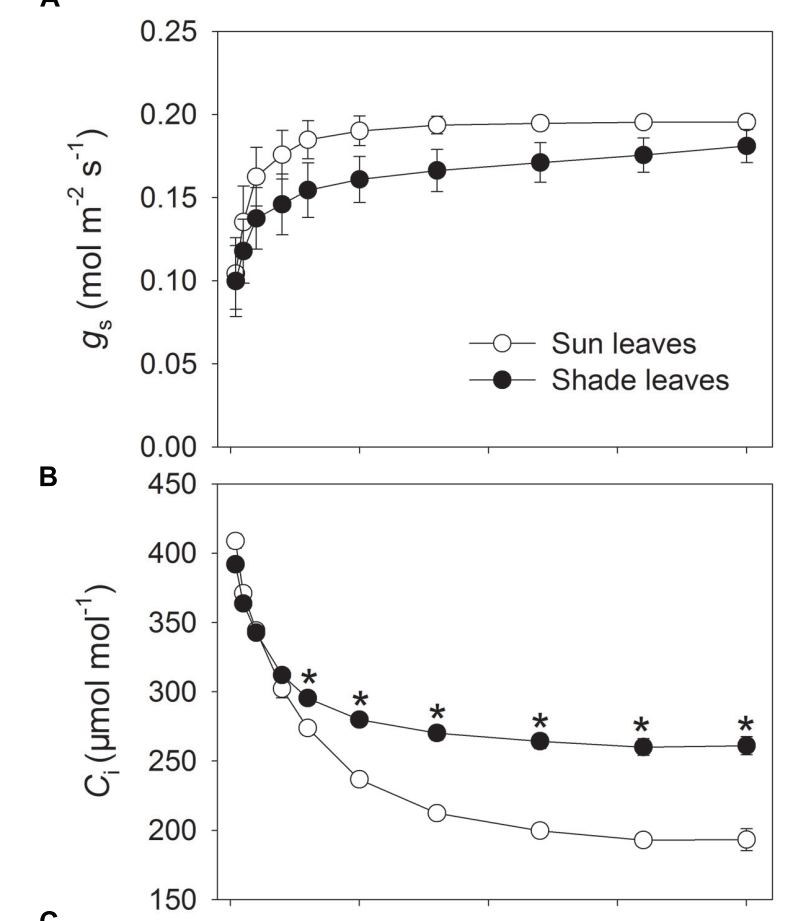

C

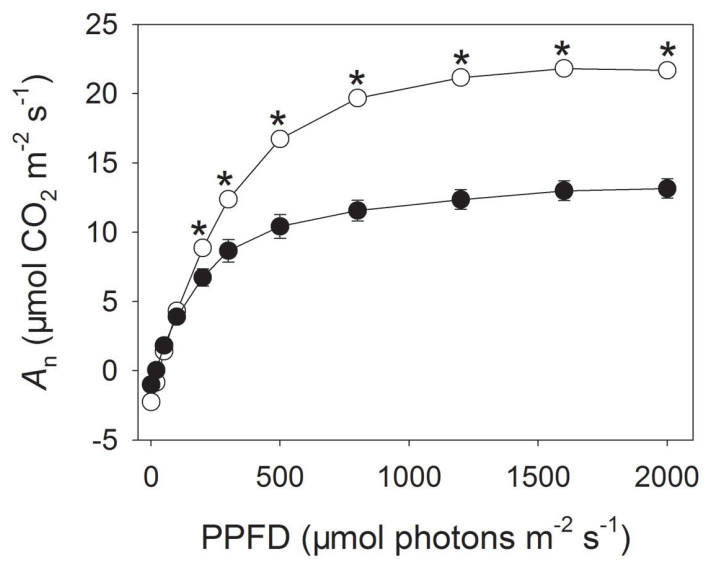

FIGURE 1 | Responses of $g_{\mathrm{s}}(\mathrm{A}), C_{\mathrm{i}}(\mathrm{B})$, and $\mathrm{CO}_{2}$ assimilation $\left(A_{\mathrm{n}}, \mathrm{C}\right)$ to incident photosynthetic photon flux density (PPFD) for sun and shade leaves of tobacco. Values are means \pm SE $(n=4)$. Significant differences between leaf types (indicated by asterisks) were examined by independent $t$-test $(P<0.05)$.

of the products of linear electron flow. Consequently, $J_{\mathrm{O}}$ was maintained at a high level under low- $C_{i}$ conditions (Figure 4C). When $C_{\mathrm{i}}$ was above $1200 \mu \mathrm{mol} \mathrm{mol}{ }^{-1}$, the affinity of Rubisco to $\mathrm{CO}_{2}$ was largely increased, such that operation of the Calvin cycle consumed most of the products of linear electron flow. Thus, $J_{\mathrm{O}}$ was maintained at a low level when the $C_{\mathrm{i}}$ was elevated (Figure 4C).

At $24^{\circ} \mathrm{C}, J_{\max }$ was 86 for sun leaves and $37 \mu \mathrm{mol} \mathrm{m}^{-2} \mathrm{~s}^{-1}$ for shade leaves, while respective $V_{\mathrm{cmax}}$ values were 91 and $41 \mu \mathrm{mol}$ $\mathrm{m}^{-2} \mathrm{~s}^{-1}$ (Figure 5). Sun leaves had significantly higher values for both $J_{\max }$ and $V_{\mathrm{cmax}}(P<0.0001)$. The latter component is linearly and positively correlated with Rubisco content (Yamori 
A

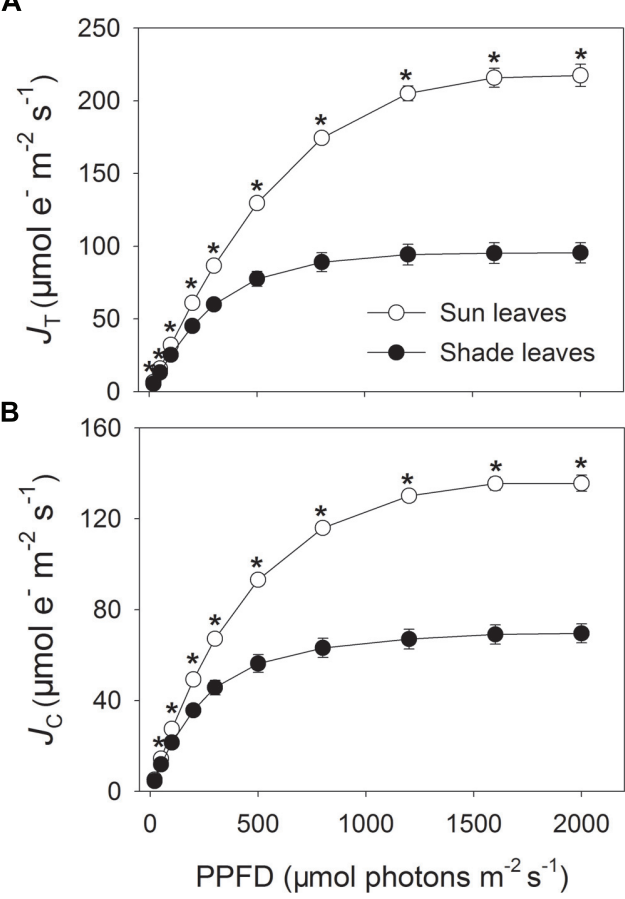

FIGURE 2 | Responses of total photosynthetic electron flow through PSII $\left(J_{T}, A\right)$, electron flow devoted to RuBP carboxylation $\left(J_{C}, B\right)$, electron flow devoted to RuBP oxygenation $\left(J_{0}, C\right)$, and $J_{0} / J_{C}$ (D) to incident
C

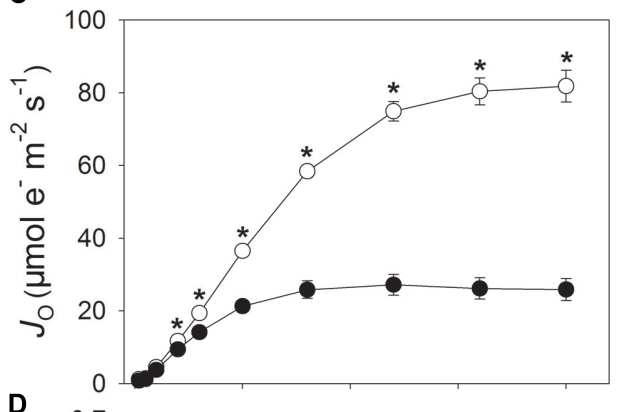

D

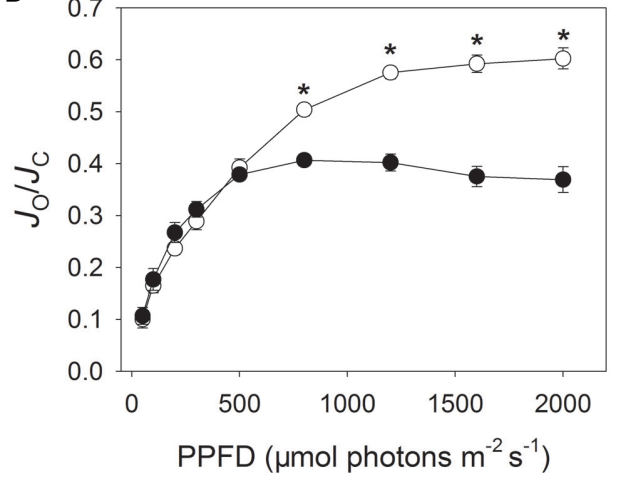

PPFD for sun and shade leaves of tobacco. Values are means \pm SE $(n=4)$. Significant differences between leaf types (indicated by asterisks) were examined by independent $t$-test $(P<0.05)$.

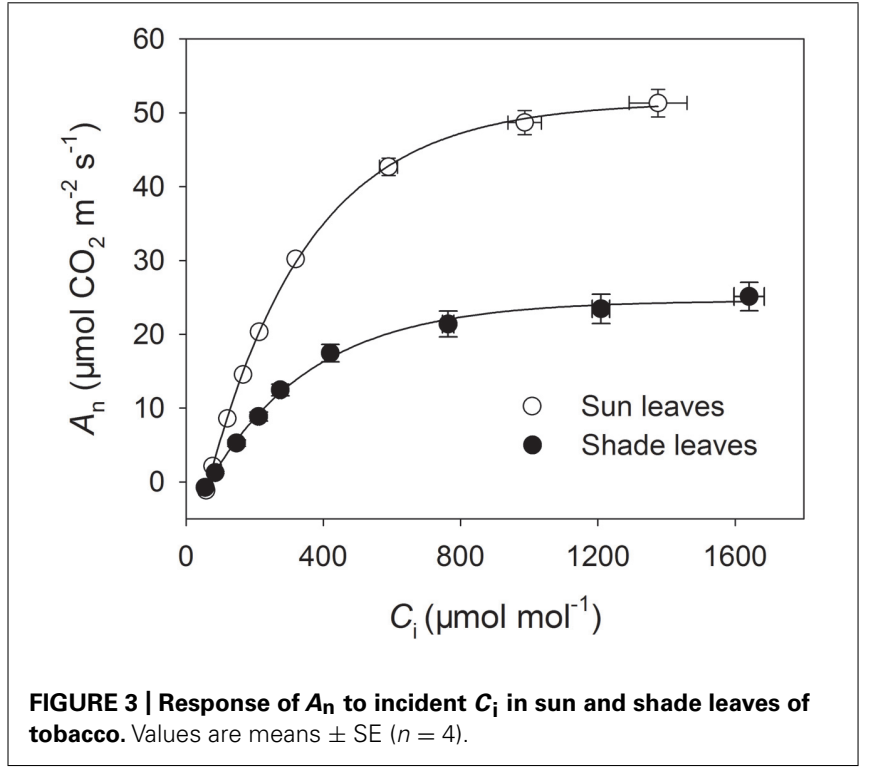

et al., 2010a). Accordingly, we also established that sun leaves had a higher Rubisco content. Corresponding $J_{\max } / V_{\text {cmax }}$ ratios were 0.94 for sun leaves and 0.92 for shade leaves. The lack of any significant difference in $J_{\max } / V_{\text {cmax }}$ ratio between leaf types indicated that the ratio of electron transport capacity to Rubisco activity did not vary between them.
The relationship between estimated Rubisco content and $J_{\mathrm{O}-\max }$ was strong and linear, based on the $A / C_{\mathrm{i}}$ curves developed at $1200 \mu \mathrm{mol}$ photons $\mathrm{m}^{-2} \mathrm{~s}^{-1}$ and $24^{\circ} \mathrm{C}$ (Figure 6). This indicated that the capacity of the photorespiratory pathway was coordinated with the level of Rubisco. Our light response curves at $24^{\circ} \mathrm{C}$ also demonstrated strong linear relationships among lightsaturated $J_{\mathrm{O}}\left(J_{\mathrm{O}-\text { sat }}\right)$, light-saturated photosynthesis $\left(A_{\mathrm{sat}}\right)$, and light-saturated $J_{\mathrm{T}}\left(J_{T \text {-sat }}\right.$; Figure 7$)$. These results suggested that high photosynthetic capacity in the sun leaves was accompanied by enhanced capacity for the photorespiratory pathway.

\section{DISCUSSION GROWTH LIGHT INTENSITY INFLUENCES THE CAPACITY OF THE PHOTORESPIRATORY PATHWAY}

Light response curves revealed that the sun leaves had greater electron flow for photorespiration under high light when $C_{\mathrm{a}}$ was $400 \mu \mathrm{mol} \mathrm{mol}{ }^{-1}$ (Figure 2C). Moreover, when exposed to high light intensities above $800 \mu \mathrm{mol}$ photons $\mathrm{m}^{-2} \mathrm{~s}^{-1}$ and at a $C_{\mathrm{a}}$ of $400 \mu \mathrm{mol} \mathrm{mol}^{-1}$, the $J_{\mathrm{O}} / J_{\mathrm{C}}$ ratio was significantly higher for sun leaves (Figure 2D). The $A / C_{\mathrm{i}}$ curves indicated that, under strong illumination, sun leaves also had higher electron flow for photorespiration associated with low $C_{\mathrm{i}}$. These results demonstrated that sun leaves have improved capacity for the photorespiratory pathway when compared with shade leaves.

Photorespiration begins with the oxygenation of RuBP catalyzed by Rubisco. The affinity of Rubisco is mainly affected by temperature and $C_{\mathrm{i}}$ (von Caemmerer, 2000). Because our sun and shade plants were grown in the same phytotron at 
A

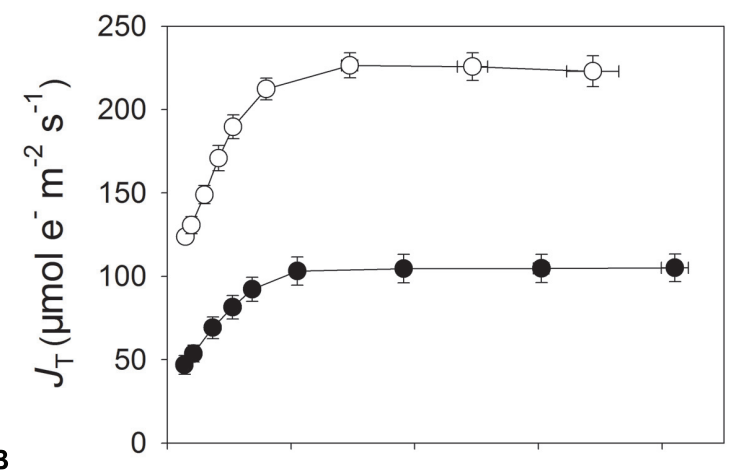

B
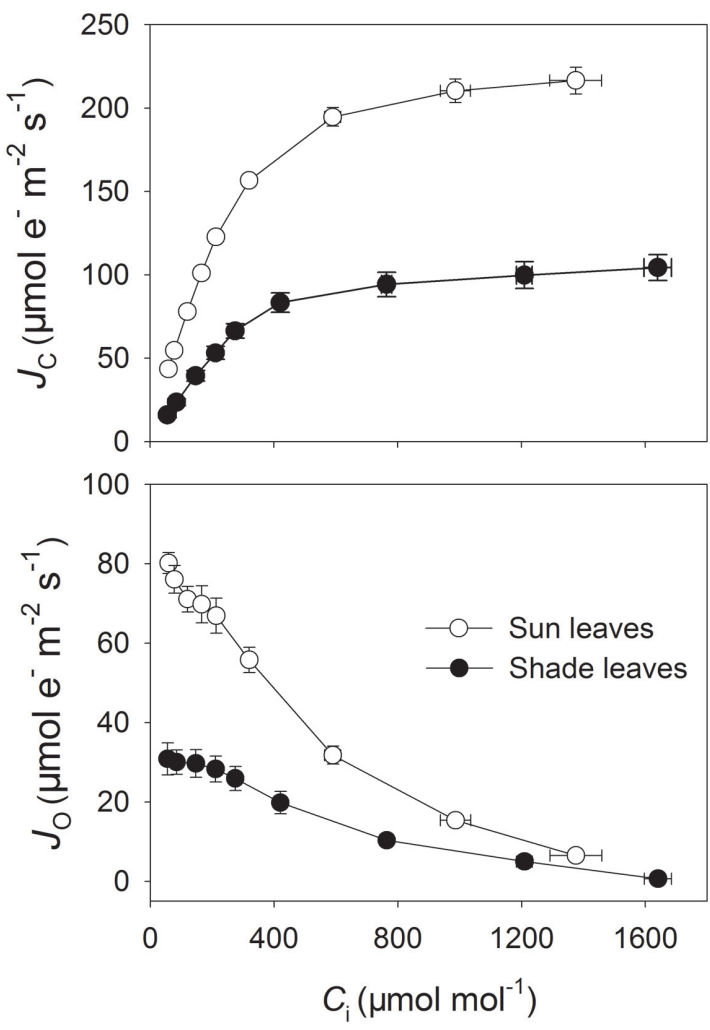

FIGURE 4 | Responses of total $J_{T}$ through PSII (A), electron flow devoted to RuBP carboxylation $\left(J_{C}, B\right)$, and electron flow devoted to RuBP oxygenation $\left(J_{0}, \mathrm{C}\right)$ to incident $C_{\mathrm{i}}$ in sun and shade leaves of tobacco. Values are means \pm SE $(n=4)$.

$24^{\circ} \mathrm{C}$, the difference in Rubisco affinity was mainly related to $C_{\mathrm{i}}$. The higher $A_{\mathrm{n}}$ in sun leaves also led to lower $C_{\mathrm{i}}$ under more intense light. This reduction in $C_{\mathrm{i}}$ increased the affinity of Rubisco for $\mathrm{O}_{2}$. Furthermore, as indicated by values for $V_{\text {cmax }}$, the sun leaves had a higher Rubisco content than did the shade leaves (Yamori etal., 2010a). Consequently, the rate of RuBP oxygenation was much higher in the sun leaves. The oxygenation of RuBP produces glycolate-2-phosphate, which then inhibits enzymes in the Calvin Cycle that are involved in regenerating RuBP (Anderson, 1971). Even low levels of glycolate-2-phosphate synthesis are detrimental to plants when this compound or other intermediates of the photorespiration process are accumulated
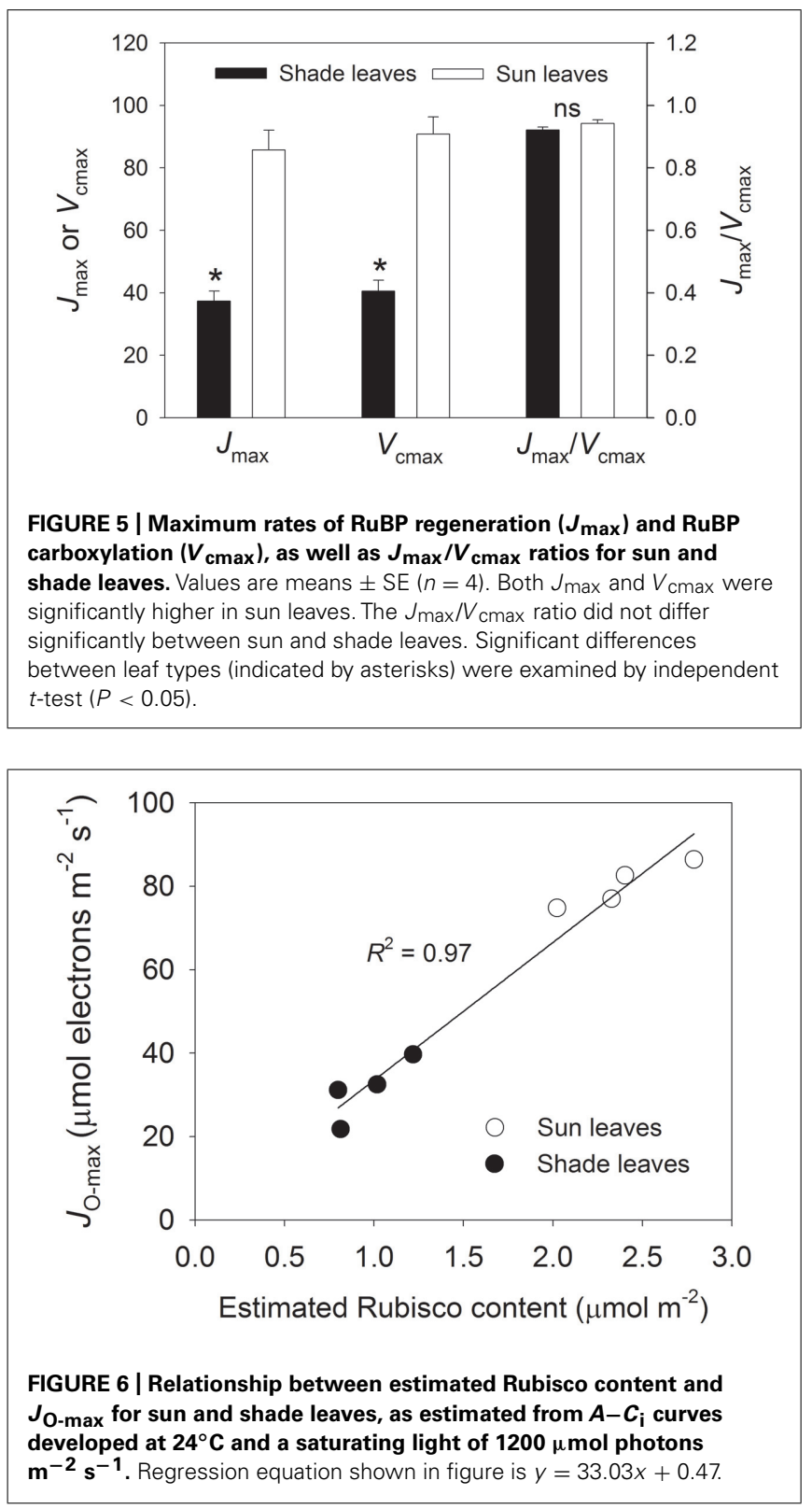

(Peterhansel and Maurino, 2011). To avoid the harmful effects of glycolate-2-phosphate and other photorespiratory intermediates such as glycine and glyoxylate (Chastain and Ogren, 1989; Campbell and Ogren, 1990; Hausler et al., 1996; Eisenhut et al., 2007), the photorespiratory pathway must be accelerated in the sun leaves. Up-regulation of glycine decarboxylase can improve the rate of photosynthesis by decreasing the glycine content (Timm et al., 2012). Therefore, the increased capacity of the photorespiratory pathway that we found in our sun leaves probably prevented the accumulation of glycolate-2-phosphate and other photorespiratory intermediates, contributing in part to the maintenance of a high rate of photosynthesis.

The photorespiratory pathway is a complex process that depends on many enzymes involved in carbon and nitrogen metabolism, such as ferredoxin-dependent Glu, Ser 
A

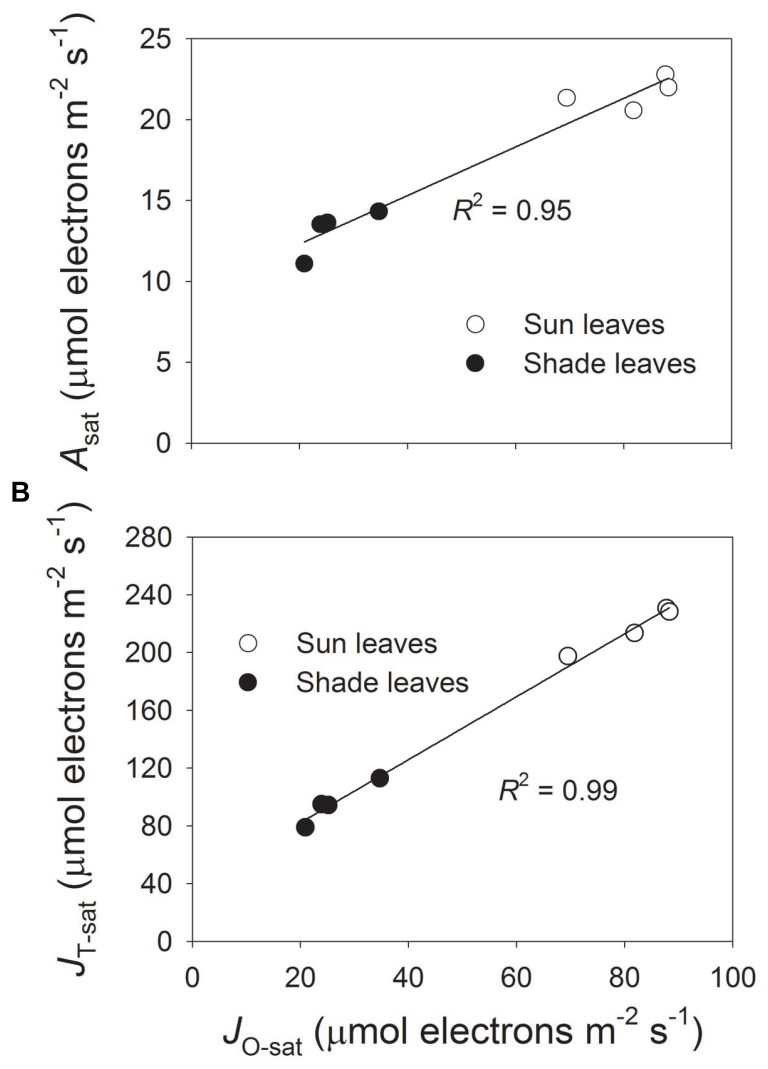

FIGURE 7 | Relationship between $J_{\mathrm{O} \text {-sat }}$ and $A_{\mathrm{n} \text {-sat }}(\mathrm{A})$ and $\boldsymbol{J}_{\mathrm{T} \text {-sat }}$ (B) for sun and shade leaves. Values were estimated from light response curves developed at $24^{\circ} \mathrm{C}$. Values for $J_{\mathrm{O} \text {-sat, }} A_{n \text {-sat }}$, and $J_{T \text {-sat }}$ represent $J_{O}, A_{n}$, and $J_{T}$, respectively, under saturating light intensity of $2000 \mu \mathrm{mol}$ photons $\mathrm{m}^{-2} \mathrm{~s}^{-1}$. Regression equations are $y=0.15 x+9.3$ (A) and $y=2.18 x+38.82$ (B)

hydroxymethyltransferase, Glu/malate transporter, glycerate kinase, and glycine decarboxylase (Somerville and Ogren, 1980, 1981, 1983; Somerville and Somerville, 1985; Blackwell et al., 1990; Wingler et al., 1997, 1999; Boldt et al., 2005). Because this pathway involves several cellular components, transporters responsible for supplying those enzymes are essential for photorespiratory processes (Eisenhut et al., 2013; Weber and Bauwe, 2013). Recently, the plastidial glycolate/glycerate transporter, PLGG1, was identified (Pick et al., 2013). Compared with shade leaves, sun leaves probably have increased synthesis of those enzymes and transporters, which then accelerates operation of the photorespiratory pathway.

\section{THE ROLE OF THE PHOTORESPIRATORY PATHWAY IN REGULATING $\mathrm{CO}_{2}$ ASSIMILATION}

The estimated Rubisco content was positively correlated with the capacity of the photorespiratory pathway in our experiments. Under $C_{\mathrm{a}}$, the higher Rubisco content and lower $C_{\mathrm{i}}$ in the sun leaves induced a higher rate of RuBP oxygenation compared with the shade leaves. The greater capacity of photorespiratory pathway enhanced RuBP regeneration. Therefore, the positive relationship between the estimated Rubisco content and $J_{\mathrm{O}-\max }$ suggested that RuBP oxygenation and regeneration are balanced via the photorespiratory pathway.

The limiting step for $\mathrm{CO}_{2}$ assimilation in leaves is mainly affected by the $J_{\max } / V_{\text {cmax }}$ ratio (Yamori et al., 2010a,b, 2011). Although our shade leaves had significantly lower values for $J_{\max }$ and $V_{\text {cmax }}$, their ratio did not differ from that of the sun leaves. According to the photosynthetic model of Yamori et al. (2011), the low $J_{\max } / V_{\text {cmax }}$ ratio means that the $A_{n}$ in sun and shade leaves is mainly limited by RuBP regeneration. Two pathways exist in $\mathrm{C}_{3}$ plants for RuBP regeneration: (1) recycling of glycerate-3-phosphate into RuBP wholly through the Calvin Cycle, and (2) recycling of glycolate-2-phosphate into glycerate-3-phosphate and then into RuBP through the photorespiratory pathway and the Calvin Cycle. The first pathway is rapid and is completed in the chloroplasts. However, the second is relative slow and involves three organelles - the chloroplasts, mitochondria, and peroxisomes (Takahashi et al., 2007; Timm etal., 2012). Thus, the capacity of the photorespiratory pathway tends to be a rate-limiting step for RuBP regeneration in both sun and shade leaves when exposed to $C_{\mathrm{a}}$ and strong illumination.

This pathway capacity can control $\mathrm{C}_{3}$ photosynthesis (Timm et al., 2012), because, if it is as low in the sun leaves as in the shade leaves, the rate of RuBP oxygenation will greatly exceed the rate of RuBP regeneration in the sun leaves. Thus, the Calvin Cycle in the sun leaves might subsequently become restricted by a lack of RuBP. To maintain a steady and high $A_{\mathrm{n}}$, RuBP oxygenation and regeneration must be balanced. For sun leaves, enhancement of the photorespiratory pathway can accelerate the rate of RuBP regeneration and helps maintain a high $A_{\mathrm{n}}$. These results, therefore, allow us to conclude that increasing the capacity of the photorespiratory pathway is an important strategy by which sun leaves from tobacco can maintain a high $A_{\mathrm{n}}$ at $C_{\mathrm{a}}$.

Although $\mathrm{CO}_{2}$ is released in the mitochondria through functioning of the photorespiratory pathway, $C_{3}$ plants trap the photorespirated and respired $\mathrm{CO}_{2}$ within single mesophyll cells (Busch etal., 2013). This trapping should then lead to a rise in chloroplast $\mathrm{CO}_{2}$ concentrations and, ultimately, improve the specificity of Rubisco to $\mathrm{CO}_{2}$. Consequently, $\mathrm{C}_{3}$ plants improve their rates of photosynthesis by re-assimilating photorespirated $\mathrm{CO}_{2}$ (Busch et al., 2013). In sun leaves, a higher rate of RuBP oxygenation and acceleration of the photorespiratory pathway can increase the rate at which this photorespiratory $\mathrm{CO}_{2}$ is released, thereby raising the $A_{\mathrm{n}}$.

\section{THE ROLE OF THE PHOTORESPIRATORY PATHWAY IN REGULATING PHOTOSYNTHETIC ELECTRON FLOW}

In higher plants, photosynthetic electron transfer from PSII to PSI converts light energy into ATP and NADPH, which is regulated by the proton gradient between the thylakoid membrane and stroma $(\Delta \mathrm{pH}$; Tikkanen and Aro, 2014). The generation of $\Delta \mathrm{pH}$ is dependent on (1) the accumulation of protons in the lumen from both the water-splitting reaction of PSII and electron transfer via $C y t b_{6} / f$, and (2) the rate of proton efflux from the lumen to stroma via ATP synthase. The energy transfer efficiency from light harvesting complex to the photosystems is enhanced by 
a decrease in $\Delta \mathrm{pH}$ but reduced by an increase in $\Delta \mathrm{pH}$ (Tikkanen and Aro, 2014). The Cyt $b_{6} / f$ complex couples electron transfer to proton transfer, which is controlled by $\Delta \mathrm{pH}$. The higher the $\Delta \mathrm{pH}$, the slower that electrons can be transferred from PSII to PSI via Cyt $b_{6} / f$ (Tikkanen and Aro, 2014). When the photorespiratory pathway is up-regulated by over-expression of the $\mathrm{H}$-protein of glycine decarboxylase, photosynthetic electron transport from PSII to PSI must increase (Timm et al., 2012). Otherwise, once photorespiratory pathway becomes impaired, the $\Delta \mathrm{pH}$ rises and causes electron transfer from PSII to PSI to be suppressed (Takahashi et al., 2007). Here, enhancement of photorespiratory pathway in the sun leaves accelerated the consumption of ATP and $\mathrm{NADPH}$, thus decreasing $\triangle \mathrm{pH}$ and favoring the $J_{\mathrm{T}}$ from PSII to PSI (Figure 7B). Taken together, we concluded that the higher capacity of the photorespiratory pathway in sun leaves regulated the $\Delta \mathrm{pH}$ and then accelerated electron transfer.

\section{CONCLUSION}

Our results strongly indicate that tobacco leaves grown under stronger irradiance have a higher rate of RuBP oxygenation compared with leaves exposed to low light levels. This is due to higher Rubisco contents and diminished $C_{\mathrm{i}}$. Meanwhile, the capacity of the photorespiratory pathway is improved in plants grown under a high light intensity, which enables them to hasten the recycling of glycolate-2-phosphate into glycerate-3-phosphate. This then regulates the balance between RuBP oxygenation and regeneration and helps to modulate the RuBP content in chloroplasts. Therefore, enhancement of photorespiratory pathway is essential for sun leaves to maintain a high $A_{\mathrm{n}}$.

\section{AUTHOR CONTRIBUTIONS}

Wei Huang, Shi-Bao Zhang, and Hong Hu: Conceived and designed the experiments. Wei Huang: Performed the experiments. Wei Huang and Shi-Bao Zhang: Analyzed the data. Wei Huang and Shi-Bao Zhang: Contributed reagents/materials/ analysis tools. Wei Huang, Shi-Bao Zhang, and Hong Hu: Contributed to the writing of the manuscript.

\section{ACKNOWLEDGMENTS}

This work was supported by the National Natural Science Foundation of China (grant 31300332), the China Postdoctoral Science Foundation, and the following scientific foundations from the Yunnan Tobacco Academy of Agriculture: 110201101003 (TS-03), 2011YN02, 2011YN03.

\section{REFERENCES}

Anderson, L. E. (1971). Chloroplast and cytoplasmic enzymes. II. Pea leaf triose phosphate isomerases. Biochim. Biophys. Acta 235, 237-244. doi: 10.1016/00052744(71)90051-9

Baker, N. R., and Rosenqvist, E. (2004). Applications of chlorophyll fluorescence can improve crop production strategies: an examination of future possibilities. J. Exp. Bot. 55, 1607-1621. doi: 10.1093/jxb/erh196

Blackwell, R. D., Murray, A. J. S., and Lea, P. J. (1990). Photorespiratory mutants of the mitochondrial conversion of glycine to serine. Plant Physiol. 94, 1316-1322. doi: 10.1104/pp.94.3.1316

Boldt, R., Edner, C., Kolukisaoglu, U., Hagemann, M., Weckwerth, W., Wienkoop, S., et al. (2005). D-GLYCERATE 3-KINASE, the last unknown enzyme in the photorespiratory cycle in Arabidopsis, belongs to a novel kinase family. Plant Cell 17, 2413-2420. doi: 10.1105/tpc.105.033993
Busch, F. A., Sage, T. L., Cousins, A. B., and Sage, R. F. (2013). C3 plants enhance rates of photosynthesis by reassimilating photorespired and respired CO2. Plant Cell Environ. 36, 200-212. doi: 10.1111/j.1365-3040.2012.02567.x

Campbell, W. J., and Ogren, W. L. (1990). Glyoxylate inhibition of ribulosebisphosphate carboxylase/oxygenase activation in intact, lysed, and reconstituted chloroplasts. Photosynth. Res. 23, 257-268. doi: 10.1007/BF00034856

Chastain, C. J., and Ogren, W. L. (1989). Glyoxylate inhibition of ribulosebisphosphate carboxylase/oxygenase activation state in vivo. Plant Cell Physiol. 30, 937-944.

Driever, S. M., and Baker, N. R. (2011). The water-water cycle in leaves is not a major alternative electron sink for dissipation of excess excitation energy when $\mathrm{CO}_{2}$ assimilation is restricted. Plant Cell Environ. 34, 837-846. doi: 10.1111/j.13653040.2011.02288.x

Eisenhut, M., Bauwe, H., and Hagemann, M. (2007). Glycine accumulation is toxic for the cyanobacterium Synechocystis sp. strain PCC 6803, but can be compensated by supplementation with magnesium ions. FEMS Microbiol. Lett. 277, 232-237. doi: 10.1111/j.1574-6968.2007.00960.x

Eisenhut, M., Pick, T. R., Bordych, C., and Weber, A. P. (2013). Towards closing the remaining gaps in photorespiration-the essential but unexplored role of transport proteins. Plant Biol. 15, 676-685. doi: 10.1111/j.1438-8677.2012. 00690.x

Evans, J. R. (1987). The relationship between electron transport components and photosynthetic capacity in pea leaves grown at different irradiances. Aust. J. Plant Physiol. 14, 157-170. doi: 10.1071/PP9870157

Farquhar, G. D., von Caemmerer, S., and Berry, J. A. (1980). A biochemical model of photosynthetic CO2 assimilation in leaves of C3 species. Planta 149, 78-90. doi: 10.1007/BF00386231

Genty, B., Briantais, J. M., and Baker, N. R. (1989). The relationship between the quantum yield of photosynthetic electron transport and quenching of chlorophyll fluorescence. Biochim. Biophys. Acta 99, 87-92. doi: 10.1016/S03044165(89)80016-9

Hanba, Y. T., Kogami, H., and Terashima, I. (2002). The effect of growth irradiance on leaf anatomy and photosynthesis in Acer species differing in light demand. Plant Cell Environ. 25, 1021-1030. doi: 10.1046/j.1365-3040.2002.00881.x

Hausler, R. E., Bailey, K. J., Lea, P. J., and Leegood, R. C. (1996). Control of photosynthesis in barley mutants with reduced activities of glutamine synthetase and glutamate synthase. 3. Aspects of glyoxylate metabolism and effects of glyoxylate on the activation state of ribulose-1,5-bisphosphate carboxylase-oxygenase. Planta 200, 388-396. doi: 10.1007/BF00231394

Hikosaka, K. (1996). Effects of leaf age, nitrogen nutrition and photon flux density on the organization of the photosynthetic apparatus in leaves of a vine (Ipomoea tricolor Cav.) grown horizontally to avoid mutual shading of leaves. Planta 198, 144-150. doi: 10.1007/BF00197597

Hikosaka, K., and Terashima, I. (1996). Nitrogen partitioning among photosynthetic components and its consequence in sun and shade plants. Funct. Ecol. 10, 335343. doi: $10.2307 / 2390281$

Krall, J. P., and Edwards, G. E. (1992). Relationship between photosystem II activity and CO2 fixation in leaves. Physiol. Plant. 86, 180-187. doi: 10.1111/j.13993054.1992.tb01328.x

Leegood, R. C., Lea, P. J., Adcock, M. D., and Hausler, R. E. (1995). The regulation and control of photorespiration. J. Exp. Bot. 46, 1397-1414. doi: 10.1093/jxb/46.special_issue.1397

Long, S. P., and Bernacchi, C. J. (2003). Gas exchange measurements, what can they tell us about the underlying limitations to photosynthesis? Procedures and sources of error. J. Exp. Bot. 54, 2393-2401. doi: 10.1093/jxb/erg262

Marenco, R. A., Gonçalves, J. F. C., and Vieira, G. (2001). Leaf gas exchange and carbohydrates in tropical trees differing in successional status in two light environments in central Amazonia. Tree Physiol. 21, 1311-1318. doi: 10.1093/treephys/21.18.1311

Miyake, C., Horiguchi, S., Makino, A., Shinzaki, Y., Yamamoto, H., and Tomizawa, K. (2005). Effects of light intensity on cyclic electron flow around PSI and its relationship to non-photochemical quenching of Chl fluorescence in tobacco leaves. Plant Cell Physiol. 46, 1819-1830. doi: 10.1093/pcp/pci197

Muraoka, H., Tang, Y. H., Terashima, I., Koizumi, H., and Washitani, I. (2000). Contributions of diffusional limitation, photoinhibition and photorespiration to midday depression of photosynthesis in Arisaema heterophyllum in natural high light. Plant Cell Environ. 23, 235-250. doi: 10.1046/j.1365-3040.2000. 00547.x 
Niinemets, Ü., Kull, O., and Tenhunen, J. D. (1998). An analysis of light effects on foliar morphology, physiology, and light interception in temperate deciduous woody species of contrasting shade tolerance. Tree Physiol. 18, 681-696. doi: 10.1093/treephys/18.10.681

Ogren, W. L. (1984). Photorespiration: pathways, regulation, and modification Annu. Rev. Plant Physiol. 35, 415-442. doi: 10.1146/annurev.pp.35.060184.002215

Oguchi, R., Hikosaka, K., and Hirose, T. (2005). Leaf anatomy as a constraint for photosynthetic acclimation: differential responses in leaf anatomy to increasing growth irradiance among three deciduous trees. Plant Cell Environ. 28, 916-927. doi: 10.1111/j.1365-3040.2005.01344.x

Peterhansel, C., and Maurino, V. G. (2011). Photorespiration redesigned. Plant Physiol. 155, 49-55. doi: 10.1104/pp.110.165019

Pick, T. R., Bräutigam, A., Schulz, M. A., Obata, T., Fernie, A. R., and Weber, A. P. (2013). PLGG1, a plastidic glycolate glycerate transporter, is required for photorespiration and defines a unique class of metabolite transporters. Proc. Natl. Acad. Sci. U.S.A. 110, 3185-3190. doi: 10.1073/pnas.1215142110

Somerville, C. R., and Ogren, W. L. (1980). Inhibition of photosynthesis in Arabidopsis mutants lacking leaf glutamate synthase activity. Nature 286, 257-259. doi: $10.1038 / 286257 \mathrm{a} 0$

Somerville, C. R., and Ogren, W. L. (1981). Photorespiration-deficient mutants of Arabidopsis thaliana lacking mitochondrial serine transhydroxymethylase activity. Plant Physiol. 67, 666-671. doi: 10.1104/pp.67.4.666

Somerville, C. R., and Ogren, W. L. (1983). An Arabidopsis thaliana mutant defective in chloroplast dicarboxylate transport. Proc. Natl. Acad. Sci. U.S.A. 80, 1290-1294. doi: 10.1073/pnas.80.5.1290

Somerville, S. C., and Somerville, C. R. (1985). A mutant of Arabidopsis deficient in chloroplast dicarboxylate transport is missing an envelope protein. Plant Sci. Lett. 37, 217-220. doi: 10.1016/0304-4211(85)90007-0

Takahashi, S., Bauwe, H., and Badger, M. R. (2007). Impairment of the photorespiratory pathway accelerates photoinhibition of photosystem II by suppression of repair but not acceleration of damage processes in Arabidopsis. Plant Physiol. 144, 487-494. doi: 10.1104/pp.107.097253

Terashima, I., Araya, T., Miyazawa, S. I., Sone, K., and Yano, S. (2005). Construction and maintenance of the optimal photosynthetic systems of the leaf, herbaceous plant and tree: an eco-developmental treatise. Ann. Bot. 95, 507-519. doi: $10.1093 / \mathrm{aob} / \mathrm{mci0} 49$

Terashima, I., and Evans, J. R. (1988). Effects of light and nitrogen nutrition on the organization of the photosynthetic apparatus in spinach. Plant Cell Physiol. 29, 143-155.

Terashima, I., and Hikosaka, K. (1995). Comparative ecophysiology of leaf and canopy photosynthesis. Plant Cell Environ. 18, 1111-1128. doi: 10.1111/j.13653040.1995.tb00623.x

Tikkanen, M., and Aro, E. M. (2014). Integrative regulatory network of plant thylakoid energy transduction. Trends Plant Sci. 19, 10-17. doi: 10.1016/j.tplants.2013.09.003

Timm, S., Florian, A., Arrivault, S., Stitt, M., and Fernie, A. R. (2012). Glycine decarboxylase controls photosynthesis and plant growth. FEBS Lett. 586, 3692 3697. doi: 10.1016/j.febslet.2012.08.027

von Caemmerer, S. (2000). Biochemical Models of Leaf Photosynthesis. Collingwood, VIC: CSIRO Publishing.

von Caemmerer, S., and Farquhar, G. D. (1981). Some relationships between the biochemistry of photosynthesis and the gas exchange of leaves. Planta 153, 376387. doi: $10.1007 / \mathrm{BF} 00384257$
Valentini, R., Epron, D., de Angelis, P., Matteucci, G., and Dreyer, E. (1995). In situ estimation of net $\mathrm{CO} 2$ assimilation, photosynthetic electron flow and photorespiration in Turkey oak (Q. cerris L.) leaves: diurnal cycles under different levels of water supply. Plant Cell Environ. 18, 631-640. doi: 10.1111/j.13653040.1995.tb00564.x

Weber, A. P., and Bauwe, H. (2013). Photorespiration-a driver for evolutionary innovations and key to better crops. Plant Biol. 15, 621-623. doi: 10.1111/plb. 12036

Wingler, A., Lea, P. J., and Leegood, R. C. (1997). Control of photosynthesis in barley plants with reduced activities of glycine decarboxylase. Planta 202, 171-178. doi: $10.1007 / \mathrm{s} 004250050116$

Wingler, A., Quick, W. P., Bungard, R. A., Bailey, K. J., Lea, P. J., and Leegood, R. C. (1999). The role of photorespiration during drought stress: an analysis utilising barley mutants with reduced activities of photorespiratory enzymes. Plant Cell Environ. 22, 361-373. doi: 10.1046/j.1365-3040.1999.00410.x

Yamori, W., Evans, J. R., and von Caemmerer, S. (2010a). Effects of growth and measurement light intensities on temperature dependence of $\mathrm{CO} 2$ assimilation rate in tobacco leaves. Plant Cell Environ. 33, 332-343. doi: 10.1111/j.13653040.2009.02067.x

Yamori, W., Noguchi, K., Hikosaka, K., and Terashima, I. (2010b). Phenotypic plasticity in photosynthetic temperature acclimation among crop species with different cold tolerances. Plant Physiol. 152, 388-399. doi: 10.1104/pp.109. 145862

Yamori, W., Nagai, T., and Makino, A. (2011). The rate-limiting step for CO2 assimilation at different temperatures is influenced by the leaf nitrogen content in several C3 crop species. Plant Cell Environ. 34, 764-777. doi: 10.1111/j.13653040.2011.02280.x

Zhang, J. L., Meng, L. Z., and Cao, K. F. (2009). Sustained diurnal photosynthetic depression in uppermost-canopy leaves of four dipterocarp species in the rainy and dry seasons: does photorespiration play a role in photoprotection? Tree Physiol. 29, 217-228. doi: 10.1093/treephys/tpn018

Zhang, W., Huang, W., Yang, Q. Y., Zhang, S. B., and Hu, H. (2013). Effect of growth temperature on the electron flow for photorespiration in leaves of tobacco grown in the field. Physiol. Plant. 149, 141-150. doi: 10.1111/ppl. 12044

Conflict of Interest Statement: The authors declare that the research was conducted in the absence of any commercial or financial relationships that could be construed as a potential conflict of interest.

Received: 11 September 2014; accepted: 18 November 2014; published online: 03 December 2014.

Citation: Huang W, Zhang S-B and Hu H (2014) Sun leaves up-regulate the photorespiratory pathway to maintain a high rate of $\mathrm{CO}_{2}$ assimilation in tobacco. Front. Plant Sci. 5:688. doi: 10.3389/fpls.2014.00688

This article was submitted to Plant Physiology, a section of the journal Frontiers in Plant Science.

Copyright (C) 2014 Huang, Zhang and Hu. This is an open-access article distributed under the terms of the Creative Commons Attribution License (CC BY). The use, distribution or reproduction in other forums is permitted, provided the original author(s) or licensor are credited and that the original publication in this journal is cited, in accordance with accepted academic practice. No use, distribution or reproduction is permitted which does not comply with these terms. 